\title{
Carbon Monoxide Emissions from Corn Silage
}

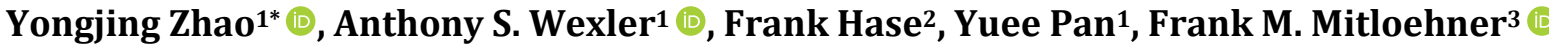 \\ ${ }^{1}$ Air Quality Research Center, University of California-Davis, Davis, USA \\ ${ }^{2}$ Institute of Meteorology and Climate Research, Karlsruhe Institute of Technology, Karlsruhe, Germany \\ ${ }^{3}$ Department of Animal Science, University of California-Davis, Davis, USA \\ Email: *yjzhao@ucdavis.edu
}

How to cite this paper: Zhao, Y.J., Wexler, A.S., Hase, F., Pan, Y. and Mitloehner, F.M. (2021) Carbon Monoxide Emissions from Corn Silage. Journal of Environmental Protection, 12, 438-453.

https://doi.org/10.4236/jep.2021.127027

Received: June 3, 2021

Accepted: July 3, 2021

Published: July 6, 2021

Copyright $\odot 2021$ by author(s) and Scientific Research Publishing Inc. This work is licensed under the Creative Commons Attribution International License (CC BY 4.0).

http://creativecommons.org/licenses/by/4.0/

\begin{abstract}
Carbon monoxide (CO) emissions from corn silage were observed using Fourier Transform Infrared (FTIR) spectroscopy and laser spectroscopy. In the first experiment, corn silage was produced using laboratory bucket silos. Air samples were collected from the bucket silos during the first week of ensiling and analyzed using a low-resolution Bruker FTIR spectrometer coupled with a long optical path length White Cell. The CO concentration in the bucket silo gas, derived from the FTIR spectra using the LINEFIT program, was as high as $48.0 \mathrm{ppm}$. In the second experiment, air samples were collected through a flux chamber from an Ag-Bag silage pile on a commercial dairy that was opened several months after ensiling. The Ag-Bag air samples were analyzed using a high-resolution Bruker FTIR spectrometer, and CO concentrations were retrieved to be $6.83 \mathrm{ppm}$, corresponding to an area emission rate of $33.7 \mathrm{mg} /\left(\right.$ hour $\left.\cdot \mathrm{m}^{2}\right)$. An LGR $\mathrm{N}_{2} \mathrm{O} / \mathrm{CO}$ gas analyzer based on infrared laser spectroscopy was also used to measure the $\mathrm{CO}$ concentrations from the same flux chamber. Elevated $\mathrm{CO}$ concentrations were observed from these silage sources. The present study revealed that $\mathrm{CO}$ was emitted by corn silage during different phases of ensiling. Annual $\mathrm{CO}$ emissions from the corn silage were estimated to be much lower than those from the well-known emission categories in San Joaquin Valley (SJV) and California, but comparable to those from food and agricultural sources in the SJV. It is also confirmed that FTIR spectroscopy is a viable method for measuring $\mathrm{CO}$ concentrations in complex gas mixtures, such as silage gas.
\end{abstract}

\section{Keywords}

Carbon Monoxide, Corn Silage, Ag-Bag, Infrared, FTIR, LINEFIT

\section{Introduction}

Carbon monoxide (CO) is a toxic criteria pollutant. Because it has about 280 
times affinity for hemoglobin, inhaling high concentrations of $\mathrm{CO}$ can result in asphyxiation. At lower concentrations, CO can lead to headaches, lack of concentration and other health effects. The OSHA standards prohibit worker exposure to $\mathrm{CO}$ concentrations of more than $50 \mathrm{ppm}$ in air averaged during an 8-hour time period [1].

Like volatile organic compounds (VOCs), $\mathrm{CO}$ forms ozone in the troposphere by reacting photochemically with nitrogen oxides $\left(\mathrm{NO}_{\mathrm{x}}\right)$ (e.g. [2]). Although the $\mathrm{O}_{3}$ forming potential of $\mathrm{CO}$ is very low in comparison with most VOCs (e.g. [3] [4]), the contributions of $\mathrm{CO}$ to the tropospheric $\mathrm{O}_{3}$ budget cannot be neglected because $\mathrm{CO}$ concentrations may be substantially higher. Whereas tropospheric VOC concentrations are typically in the tens of ppb levels, CO concentrations vary from hundreds $\mathrm{ppb}$ in clean areas to $\mathrm{ppm}$ levels in polluted areas and are much higher near CO emission sources (e.g. [5] [6]).

$\mathrm{CO}$ has been classified as one of the six criteria pollutants in the US together with $\mathrm{O}_{3}$, lead, sulfur oxides $\left(\mathrm{SO}_{2}\right)$, nitrogen oxides $\left(\mathrm{NO}_{\mathrm{x}}\right)$, and particulate matter (PM) [7]. Emission sources of CO have been widely studied and most of them are well known. A very common emission source of $\mathrm{CO}$ is the incomplete combustion of carbonaceous materials, such as gasoline, oil, coal, and wood, in natural and anthropogenic processes such as motor vehicles equipped with internal combustion engines, wildfires and biomass burning. However, there may be some unexpected $\mathrm{CO}$ emission sources that warrant further investigation.

Silo gas is produced during ensiling, particularly in the initial few weeks of ensiling. Because silo gas had been reported to cause serious respiratory disease and death of humans working near or in silos ([8] and reference therein), it is a well-known poisonous gas mixture. The majority of silo gas is nitrogen dioxide $\left(\mathrm{NO}_{2}\right)$, which can cause human respiratory disease and even be lethal. In addition to $\mathrm{NO}_{2}$, other chemical components were also observed in the silo gas, such as $\mathrm{CO}_{2}, \mathrm{~N}_{2} \mathrm{O}$, VOCs [9] [10] [11] [12] [13]. Because silo gas is a complex mixture, it may contain constituents that have not been identified yet and might be of relevance for atmospheric chemistry, air pollution, and public health. The present paper reports our observations of $\mathrm{CO}$ emitted by corn silage, which constitutes a new $\mathrm{CO}$ emission source and therefore a potential concern for both air quality and public health.

The San Joaquin Valley (SJV) in central California has the worst air quality designation in the US in terms of ground-level $\mathrm{O}_{3}$ and PM. At the same time, the density of dairy farms in the SJV is the highest in the US, which feeds more than $16 \%$ of US milk cows in 2019 and 2020 [14] [15]. Because silage is a major feed for dairy cows and is produced locally from fresh corn crops, production and consumption of silage in the SJV may contribute to $\mathrm{O}_{3}$ production through the $\mathrm{CO}+\mathrm{NO}_{\mathrm{x}} \rightarrow \mathrm{O}_{3}$ cycle, as well as the VOC $+\mathrm{NO}_{\mathrm{x}} \rightarrow \mathrm{O}_{3}$ cycle. According to USDA statistical reports, 10.1 million tons of corn for silage were produced in California in 2020 , which was about $7.3 \%$ of total production in the US and placed California the second place in corn silage production [16] [17]. 
Although many studies have been conducted on silage emissions (e.g. [11] [12] [13] [18] [19]), thorough studies using new monitoring techniques would identify more unknown components emitted by silage, determine their emission rates, and provide more useful data to help with reducing silage emissions. The present paper also demonstrates that FTIR spectroscopy can be used to investigate complex mixtures in air emissions, such as those from silages. Because the FTIR spectroscopic technique has been used for real-time measurements of trace gaseous species (e.g. [20] [21]), it is an excellent tool for real-time monitoring of air emissions from silages and other complex sources.

\section{Equipment and Analytical Methods}

\subsection{Laboratory Bucket Silos, Ag-Bag Silage, and Air Sample Collections}

The present paper contains data from two different projects. Because the infrared spectroscopic measurements of $\mathrm{CO}$ in silage emissions were not included in the original two project plans, the present paper reports these additional findings.

Various types of laboratory silos had been used for decades to simulate the conditions of large-scale silos for different purposes (e.g. [22] [23] and references therein). Making corn silage in laboratory bucket silos and collecting gas samples from the buckets have been described by Hafner et al. [12]. Twelve kilograms of corn forage were manually compressed in 18.9-liter buckets. Excess silage gases from the bucket silos filled 5-liter Tedlar bags (SKC-West Inc., Fullerton, CA) during the first week after ensiling. Gas samples were then analyzed by various analyzers. Because the bucket silo experiment was originally designed to evaluate the effects of silage additives on the production of volatile organic compounds (VOCs) within corn silage using gas chromatography, only one bag of silage gas was analyzed using the FTIR spectrometer. In addition to reporting VOC measurements, Hafner et al. [12] presented typical properties of the silage produced in the bucket silos and concluded that they were within or close to the recommended values. Therefore, the corn silage produced in the bucket silos was normal, and the gas samples collected from the bucket silos should be representative of the regular ensiling processes.

Making and storing silage in so called Ag-Bags is a relatively new technique to produce silage under commercial conditions. Unlike the traditional silage piles or silos, large elongated plastic bags were filled with chopped corn forage, compressed, and sealed for ensiling. Excessive gas produced in the initial phase of ensiling was periodically released by small vent holes during the first $1-2$ weeks of ensiling. Then the plastic bags were sealed for several months until the silage inside the Ag-Bag was ready for feeding.

Collecting air samples from emission surfaces using flux chambers has been widely reported (e.g. [24] [25] and references therein). In the present study, a portion of the silage face surface was covered by a flux chamber as soon as the 
Ag-Bag was opened and defaced for feeding, as shown in Figure 1 (the dome shaped transparent device was the flux chamber). A $20 \mathrm{lpm}$ of ambient air was supplied to the flux chamber as sheath flow through a Teflon tubing, and about $10 \mathrm{lpm}$ of air samples was taken out from the flux chamber through another Teflon tubing for analysis. Air samples from the flux chambers were either filled into Tedlar bags for offline analysis or fed to gas analyzers for real-time measurements. Figure 1 also shows other equipment and devices, but these are not relevant to the current discussion.

\subsection{Analytical Equipment}

Two FTIR spectrometers were employed in the present study. One instrument was a Bruker Tensor 27 (Bruker Optics, Inc., Germany) with a spectral resolution of $1 \mathrm{~cm}^{-1}$, which covered the spectral range from 850 to $7000 \mathrm{~cm}^{-1}$ with a mid-infrared (MIR) source, a KBr beam-splitter, and a Cryo-cooled MCT detector. A White Cell with variable optical path length between 3.2 - 64 meters and 16 liters volume was coupled to the Bruker Tensor FTIR spectrometer. Gas samples in the Tedlar bag from the laboratory bucket silo were analyzed using this FTIR spectrometer. The second instrument was a Bruker IFS 125HR FTIR spectrometer (Bruker Optics, Inc., Germany) with a high-resolution greater than 0.001 $\mathrm{cm}^{-1}$ and broad spectral region from ultraviolet (UV) to far infrared (far-IR). In this case, a $40-\mathrm{cm}$ long absorption cell was used to analyze air samples. Air samples from two Tedlar bags from the Ag-Bag samples were analyzed using this FTIR spectrometer. A high spectral resolution LGR $\mathrm{N}_{2} \mathrm{O} / \mathrm{CO}$ gas analyzer based on Laser spectroscopy (Los Gatos Research, San Jose, CA) was used to simultaneously monitor $\mathrm{CO}$ and $\mathrm{N}_{2} \mathrm{O}$ concentrations. LGR analyzers utilize a unique laser absorption technology called Off-Axis Integrated Cavity Output Spectroscopy (OA-ICOS) with high precision ( $0.1 \mathrm{ppb}$ in 1 second) and a wide dynamic range $(0-10 \mathrm{ppm})$. Air samples collected from the Ag-Bag silage through the flux chamber were analyzed in real time by this LGR analyzer.

\subsection{LINEFIT Program}

An instrumental line shape retrieval program, called LINEFIT, developed by

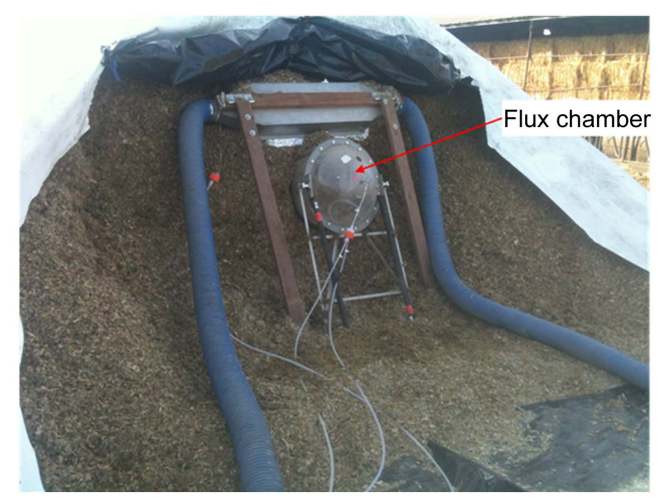

Figure 1. Flux chamber covering the surface of an Ag-Bag silage face for air sampling. 
Hase at the Karlsruhe Institute of Technology in Germany [26], was used to analyze the FTIR spectra to derive the gas concentrations inside the White Cell. The LINEFIT code is in wide use within the FTIR group of the NDACC (Network for Detection of Atmospheric Composition Change,

https://www.ndsc.ncep.noaa.gov/) and TCCON (Total Carbon Column Observing Network [21]) for the analysis of reference gas cell spectra recorded with high-resolution spectrometers [27] [28], but has also been used for the analysis of spectra observed with low-resolution spectrometers [29].

\section{FTIR Spectra of the Silage Gases}

\subsection{Low Resolution FTIR Spectra and Verification of $\mathrm{CO}$ in the Bucket Silo Gas}

Recording of the infrared spectra from silo gas using the Bruker Tensor 27 FTIR spectrometer was described in detail in the previous paper for $\mathrm{N}_{2} \mathrm{O}$ detection in silo gas [13]. The only exception is that no standard CO spectrum was recorded because $\mathrm{CO}$ was not in the original project plan and therefore not noticed when the air samples were analyzed by FTIR spectrometer. Due to the well-known physical/optical properties of $\mathrm{CO}$ gas, its infrared absorption spectra can be accurately calculated and identified without comparing to its pure gas spectra. One important note from our previous paper is that the air samples from the bucket silos were diluted by a factor of 3.2 in the White Cell when their FTIR spectra were recorded.

Figure 2 shows an infrared spectrum of the bucket silo gas (red) in the 2000 $2250 \mathrm{~cm}^{-1}$ spectral region at $1 \mathrm{~cm}^{-1}$ spectral resolution, together with the simulated

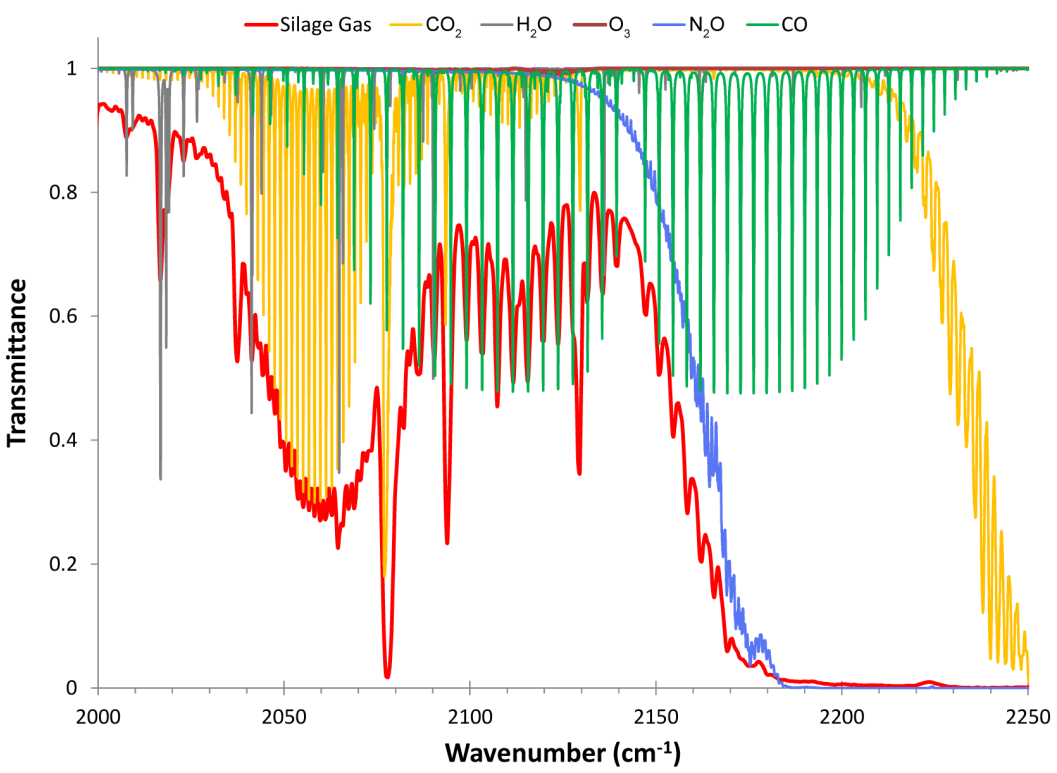

Figure 2. Low resolution FTIR spectrum of air samples from the bucket silos (red) recorded by a Bruker Tensor 27 FTIR spectrometer in a White Cell of $64 \mathrm{~m}$ optical length. Simulation spectra of gases $\mathrm{CO}_{2}$ (yellow), $\mathrm{H}_{2} \mathrm{O}$ (grey), $\mathrm{O}_{3}$ (brown), $\mathrm{N}_{2} \mathrm{O}$ (blue), and $\mathrm{CO}$ (green) by LINEFIT program are also shown. 
infrared spectra of 5 gases whose absorption fall in the same spectral region: 1) $\mathrm{CO}_{2}$, 2) $\mathrm{H}_{2} \mathrm{O}$, 3) $\mathrm{O}_{3}$, 4) $\mathrm{N}_{2} \mathrm{O}$, and 5) $\mathrm{CO}$ that were generated by the LINEFIT program. The simulation procedure was described in detail in Zhao et al. [13] and thus will not be repeated here. Because the gas concentrations in the bucket silo gas were unknown when the simulation spectra were generated, to better identify the individual absorptions of the five gases in the silo gas spectra, their concentrations were scaled so that their absorptions close to the intensities of the FTIR spectrum in the following absorption regions: 1) $\mathrm{H}_{2} \mathrm{O}$ between $2000-2030$ $\mathrm{cm}^{-1}$, 2) $\mathrm{CO}_{2}$ between $2030-2080 \mathrm{~cm}^{-1}$, 3) CO between $2080-2150 \mathrm{~cm}^{-1}$, and 4) $\mathrm{N}_{2} \mathrm{O}$ between $2150-2250 \mathrm{~cm}^{-1}$. It should be mentioned that the final gas concentrations were accurately retrieved by the LINFIT program as described later, not during the simulation. Due to the overlapping absorptions of $\mathrm{CO}, \mathrm{N}_{2} \mathrm{O}$ and $\mathrm{CO}_{2}$ above $2150 \mathrm{~cm}^{-1}$ and by $\mathrm{H}_{2} \mathrm{O}, \mathrm{CO}_{2}$, and $\mathrm{CO}$ below $2080 \mathrm{~cm}^{-1}$, these spectral regions are not optimal for the quantification of $\mathrm{CO}$. By contrast, $\mathrm{CO}$ lines are prominent features in the silo gas spectra between $2080-2150 \mathrm{~cm}^{-1}$, clearly indicating the presence of $\mathrm{CO}$ in the silo gas.

\subsection{High Resolution FTIR Spectra and Verification of CO in the Ag-Bag Silage Gas}

Figure 3 shows an infrared spectrum of the air sample from Ag-Bag silage (red) in the $2090-2210 \mathrm{~cm}^{-1}$ spectral region with $0.001 \mathrm{~cm}^{-1}$ resolution, together with the simulated infrared spectra of 3 gases whose absorption fall in this spectral region: 1) $\mathrm{H}_{2} \mathrm{O}$, 2) $\mathrm{N}_{2} \mathrm{O}$, and 3) CO generated by the LINEFIT program. In order to compare these spectra in the figure, the silage spectrum was downward shifted by 0.02 . Because the absorption lines of individual gases are well separated in the

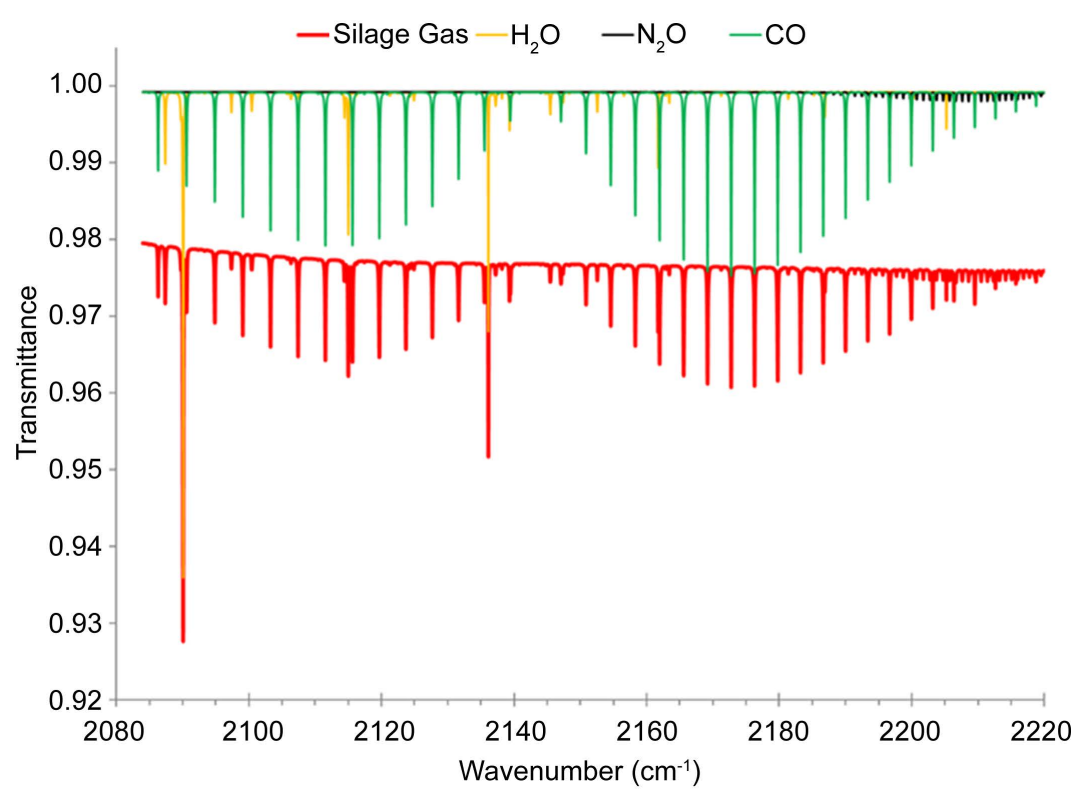

Figure 3. High resolution FTIR spectrum of air samples from the Ag-Bag silage (red) recorded by a Bruker IFS $125 \mathrm{HR}$ FTIR spectrometer in a $40 \mathrm{~cm}$ cell. Simulation spectra of gases $\mathrm{H}_{2} \mathrm{O}$ (yellow), $\mathrm{N}_{2} \mathrm{O}$ (black), and $\mathrm{CO}$ (green) by LINEFIT program are also shown. 
high resolution FTIR spectra, it is easier to identify them. Figure 3 shows that $\mathrm{CO}$ absorption lines are less interfered with other absorption lines. Although some of the $\mathrm{H}_{2} \mathrm{O}$ and $\mathrm{N}_{2} \mathrm{O}$ absorption lines fall in the same spectral region, most of them are isolated from the $\mathrm{CO}$ lines.

\section{Retrievals of FTIR Spectra Using LINEFIT Program}

\subsection{Selection of the Spectral Windows}

Considerations for selecting spectral windows when retrieving $\mathrm{N}_{2} \mathrm{O}$ were described in Zhao et al. [13]. A similar principle applies when retrieving $\mathrm{CO}$ from the silage gas FTIR spectra. The selected spectral windows should include as many $\mathrm{CO}$ absorption lines as possible and exclude significant interferences. Figure 2 shows the spectral region of the CO absorption bands from 2000 to 2250 $\mathrm{cm}^{-1}$. There are two major interferences, one by $\mathrm{CO}_{2}$ absorptions peaking at $2060 \mathrm{~cm}^{-1}$ and the other by $\mathrm{N}_{2} \mathrm{O}$ absorptions, which saturate above $2180 \mathrm{~cm}^{-1}$. As a result, the spectral region between $2050-2175 \mathrm{~cm}^{-1}$ was selected in this study to retrieve $\mathrm{CO}$ concentrations from the low resolution FTIR spectra.

Because of less interference of $\mathrm{N}_{2} \mathrm{O}$ absorption in the FTIR spectrum of the Ag-Bag air samples, $\mathrm{CO}$ absorptions lines can still be seen beyond $2180 \mathrm{~cm}^{-1}$, as shown in Figure 3, which is different from the FTIR spectrum in Figure 2. Therefore, a spectral region from 2090 to $2210 \mathrm{~cm}^{-1}$ was selected for CO retrieval from high-resolution FTIR spectra.

\subsection{Retrieval of Low Resolution FTIR Spectra of the Bucket Silo Gas}

The CO concentration in the bucket silo gas was retrieved from the spectral window between $2025-2175 \mathrm{~cm}^{-1}$. The spectral fitting results are shown in Figure 4. FTIR and fitted spectra are shown on the low portion of the figures in red and blue, respectively. Their residuals are shown on the upper portion of the figures in black. Four narrow subregions indicated by green dotted lines with higher residuals are de-weighted in the spectral fitting to minimize the propagation of these residuals onto the CO results. In Figure 4, the CO column in the White Cell retrieved from the $2025-2175 \mathrm{~cm}^{-1}$ window was $2.35 \times 10^{22} \mathrm{~m}^{-2}$, equivalent to $15.0 \mathrm{ppm} \mathrm{CO}$ in the White Cell. Because the $\mathrm{CO}$ concentration in the Tedlar bag was diluted by a factor of 3.2 when the samples were introduced into the White Cell, the $\mathrm{CO}$ concentrations in the bucket silos gas are estimated to be $48.0 \mathrm{ppm}$. According to the $\mathrm{N}_{2} \mathrm{O}$ retrieval from silo gas in Zhao et al. [13], the estimated uncertainty in retrieving $\mathrm{N}_{2} \mathrm{O}$ concentrations was less than $2 \%$. The uncertainty of $\mathrm{CO}$ retrieval from FTIR spectra is estimated to be in the order of $3 \%$ based on CO line intensities and instrument line shape.

To our knowledge, $\mathrm{CO}$ concentrations in silage gas have never been reported in the literature. Our results show that $\mathrm{CO}$ concentration was as high as 48.0 ppm in the bucket silo gas. Considering the OSHA standards level prohibiting worker exposure to $\mathrm{CO}$ more than $50 \mathrm{ppm}$ in the air averaged during an 8-hour 


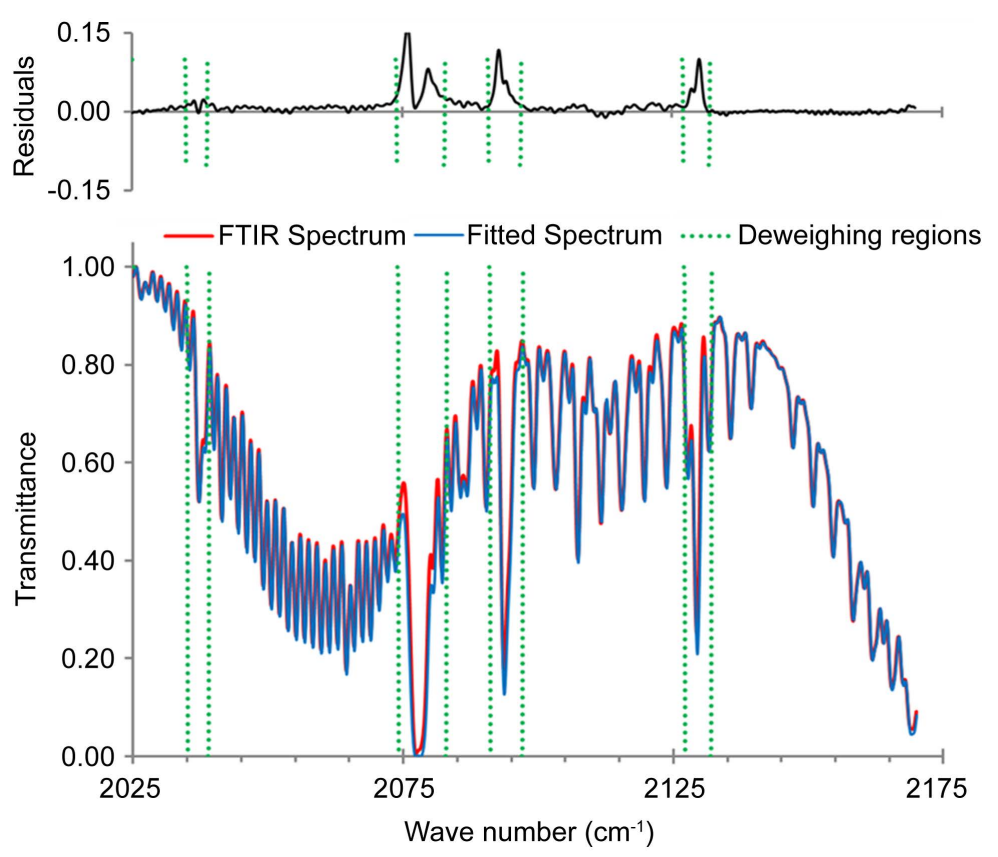

Figure 4. Retrieval of the bucket silo air samples from a low-resolution spectrum between $2025-2175 \mathrm{~cm}^{-1}$. The FTIR spectrum (red) and the fitted spectrum (blue) are shown on the bottom panel. The differences between FTIR and fitted spectra (Residuals) are shown in top panel in black. The de-weighing spectral regions are shown in green dotted lines on both top and bottom panels.

time period, high CO concentrations in silage supports warnings, in addition to those about $\mathrm{NO}_{2}$, regarding potential health effects of humans working in silos ([8] and reference therein).

\subsection{Retrieval of High Resolution FTIR Spectra of the Ag-Bag Silage Gas}

Two bags of air samples were collected from the Ag-Bag silage through a flux chamber and analyzed using a high resolution FTIR spectrometer. CO concentrations were retrieved from the FTIR at a spectral window between $2090-2210$ $\mathrm{cm}^{-1}$. The spectral fitting results are shown in Figure 5. Similar to Figure 4, FTIR and fitted spectra are shown on the low portion of the figures in red and blue, respectively. Their residuals are shown in the upper portion of the figures in black. In Figure 5, the CO column retrieved from the $2090-2210 \mathrm{~cm}^{-1}$ window was $6.53 \times 10^{19} \mathrm{~m}^{-2}$, equivalent to $6.83 \mathrm{ppm} \mathrm{CO}$ in the sample bag. Surprisingly, the retrieved CO concentrations in the two sample bags collected simultaneously were the same. Because two different methods had been used to collect air samples from bucket silos and Ag-Bag silage, the CO concentrations from the two types of silages cannot be directly compared. When air samples were collected directly from the bucket silos, $\mathrm{CO}$ concentration in the sample bag would be the concentration in the silo gas. When the air samples were collected from the Ag-Bag silage through a flux chamber, $\mathrm{CO}$ concentrations in the sample bags are used to determine the area $\mathrm{CO}$ emission rate from the $\mathrm{Ag}$-Bag silage. Because 


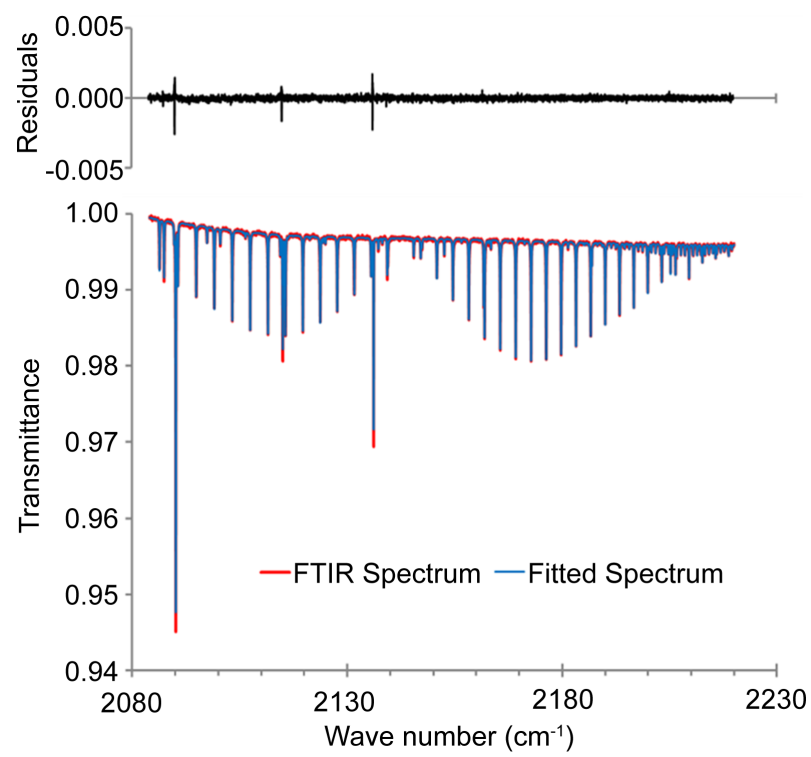

Figure 5. Retrieval of the Ag-Bag silage samples from high resolution FTIR spectrum at window between $2090-2210 \mathrm{~cm}^{-1}$. The FTIR spectrum (red) and the fitted spectrum (blue) are shown on the bottom panel. The differences between FTIR and fitted spectra (residuals) are shown in top panel in black.

sheath flow was $20 \mathrm{lpm}$ when the air samples were collected from the Ag-Bag silage through the flux chamber, the area emission rate of $\mathrm{CO}$ from the Ag-Bag silage was determined to be $29.0 \mathrm{~mL} /\left(\right.$ hour $\cdot \mathrm{m}^{2}$ ) in volume or $33.7 \mathrm{mg} /\left(\right.$ hour $\cdot \mathrm{m}^{2}$ ) in mass, when the Ag-Bag was opened several months after ensiling.

A side note is that $\mathrm{N}_{2} \mathrm{O}$ concentrations retrieved from this spectral window were $0.35 \mathrm{ppm}$ and $0.38 \mathrm{ppm}$ in the two sampling bags. Because these concentrations are typical for ambient $\mathrm{N}_{2} \mathrm{O}$ concentrations, no elevated $\mathrm{N}_{2} \mathrm{O}$ emissions were observed from the Ag-Bag silage several months after ensiling using FTIR spectrometer.

\subsection{Real-Time CO Concentrations from Ag-Bag Silage}

Figure 6 shows the real-time raw $\mathrm{CO}$ data from Ag-Bag silage samples measured by a high spectral resolution LGR $\mathrm{N}_{2} \mathrm{O} / \mathrm{CO}$ analyzer. The blue dash line indicates sampling locations. There were eight sampling locations in the sampling system for different experiments and four of them were used for sampling from Ag-Bag silage. Because of the pre-configurations of data collection, the sampling locations in Figure 6 were not selected consecutively. Air samples were drawn by a Teflon coated diaphragm pump at $10 \mathrm{lpm}$ from locations \#7 (Flux Chamber inlet, ambient air) and \#3 (Flux Chamber outlet, silage samples) and then fed to various gas analyzers for real-time measurements. Only raw $\mathrm{CO}$ data measured by the LGR $\mathrm{N}_{2} \mathrm{O} / \mathrm{CO}$ analyzer are presented here. The red line shows $\mathrm{CO}$ measurements and the green line covers the period when the two Tedlar bags were filled for FTIR analysis. Although data from locations \#1 and \#2 are shown in Figure 6 for data continuity, they are not discussed here because they were not relevant to this study. 


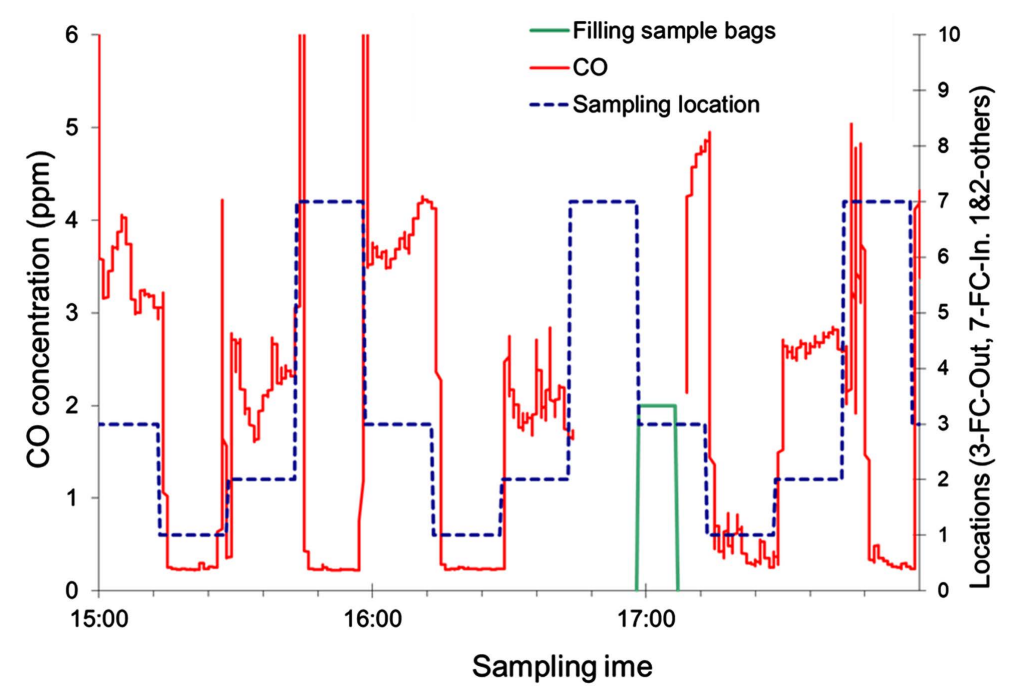

Figure 6. Real-time measurements of $\mathrm{CO}$ from Ag-Bag silage by LGR $\mathrm{N}_{2} \mathrm{O} / \mathrm{CO}$ analyzer. The blue dash line indicates the sampling locations, the red line shows raw $\mathrm{CO}$ concentrations, and the green line covers the period when the two Tedlar bags were filled-up for FTIR analysis.

It can be seen that $\mathrm{CO}$ concentrations were low in the flux chamber inlets (\#7, ambient air) and elevated in the flux chamber outlet (\#3, silage air samples) by about 3 - 5 ppm. Figure 6 presents raw CO data of the LGR analyzer to confirm that high $\mathrm{CO}$ concentrations were also observed with an independent monitoring device. There are some CO spikes when sampling locations were switched. Because the switch was achieved using a mechanical rotary valve, it took a longer time to switch to or away from \#7, which might have caused a pressure fluctuation in the air samples and influenced the LGR analyzer. CO data from the LGR analyzer are not available when the two Tedlar bags were filled, as shown in Figure 6.

\section{Discussion}

California is a leading dairy state in the nation. In 2019, about $18.5 \%$ of US dairy cows were farmed, and $18.6 \%$ of US milk/cream was produced in California [14] [15] [30], ranking California the \# 1 state in the US. The number of dairy cows in the SJV was about $87.3 \%$ of the state total in 2019 [14]. Because silage is a major feed for dairy cows, California and the SJV dairy farms might be an additional contributor to the state's $\mathrm{CO}$ budget due to the $\mathrm{CO}$ emissions from silage. Considering that $\mathrm{CO}$ is an important $\mathrm{O}_{3}$ precursor, $\mathrm{CO}$ emissions from silage would also have contributed to the production of $\mathrm{O}_{3}$ in California, particularly in the $\mathrm{SJV}$ where high ground-level $\mathrm{O}_{3}$ concentrations are observed. However, $\mathrm{CO}$ emitted from silage has not been included in the $\mathrm{O}_{3}$ budget yet because this $\mathrm{CO}$ emission source had not been previously reported. $\mathrm{CO}$ is also a gas hazardous to human health. Due to the continuous emission from silage during various ensiling phases, $\mathrm{CO}$ is present and potentially at concentrations that might be healthrelevant. 
Because no information was available on $\mathrm{CO}$ emission from silage, the importance of its contribution to the $\mathrm{CO}$ budget has been unclear. To understand its importance, approaches similar to estimating the $\mathrm{N}_{2} \mathrm{O}$ contribution in Zhao et al. [13] were applied here to estimate the $\mathrm{CO}$ contribution. Although this work cannot provide enough data to quantitatively determine the $\mathrm{CO}$ emissions from silage, we may be able to roughly estimate it based on our limited observational data and several assumptions. The volume of the bucket silos was 18.9 liters and corn forage compressed in the bucket silos was $12 \mathrm{~kg}$. Assuming all CO gas emitted from one bucket silo was captured in one 5-liter Tedlar bag, in which the $\mathrm{CO}$ concentration was measured at about $48 \mathrm{ppm}$, the $\mathrm{CO}$ mass emission from one bucket silo was about $300 \mu \mathrm{g}$ or the mass emission rate was about $25 \mu \mathrm{g}$ per kg corn forage. This assumption could have underestimated the CO emission rate from the bucket silos because: 1) the silo gas that remained in the bucket silo container in the initial ensiling phase was not included to determine the CO emissions, and 2) CO was continuously emitted for several months after the initial ensiling.

We took two approaches to estimate the impact of these $\mathrm{CO}$ emissions. The first approach was based on silage production and CO mass emission rates from silage. In 2019, about 9.83 million tons of corn silage were produced in the SJV and 10.7 million in California [31]. The CO emission from the corn silages would be about 0.25 tons per year in the SJV and 0.27 tons per year in California in 2019. The second approach was based on the silage consumptions by milk cows. The calculated yearly need for corn silages by milking cows was 10.9 tons per cow per year [32]. The number of milk cows in 2020 was reported 1.51 million heads in the SJV and 1.72 million in California [15] [30] [33]. Therefore, total $\mathrm{CO}$ emissions from the corn silages in 2020 would be 0.41 tons per year in the SJV and 0.47 tons per year in California. Despite large uncertainty in estimating the annual CO emissions from silages based on silage production and consumption, both estimates suggest that $\mathrm{CO}$ emissions from the corn silages could range $0.25-0.41$ tons per year in the SJV and $0.27-0.47$ tons per year in California. The CO Emission Projections by Summary Category in California counties are available online [34]. The projected $\mathrm{CO}$ emissions by some major categories in the SJV and California in 2020 are summarized in Table 1. The estimated

Table 1. CO emission projects by category in the SJV and Calfirona in 2020 [34] and CO emissions from the corn silages estimated in this study.

\begin{tabular}{cccccccc}
\hline \multirow{2}{*}{ Regions } & $\begin{array}{c}\text { Fuel } \\
\text { Combustion } \\
(\mathrm{T} / \mathrm{D})^{\mathrm{a}}\end{array}$ & $\begin{array}{c}\text { Waste } \\
\text { Disposal } \\
(\mathrm{T} / \mathrm{D})\end{array}$ & $\begin{array}{c}\text { Industrial } \\
\text { Processes } \\
(\mathrm{T} / \mathrm{D})\end{array}$ & $\begin{array}{c}\text { Food \& } \\
\text { Agriculture } \\
(\mathrm{T} / \mathrm{D})\end{array}$ & $\begin{array}{c}\text { On-road } \\
\text { Vehicles } \\
(\mathrm{T} / \mathrm{D})\end{array}$ & $\begin{array}{c}\text { Mobile } \\
\text { Source } \\
(\mathrm{T} / \mathrm{D})\end{array}$ & $\begin{array}{c}\text { Corn } \\
\text { Silage } \\
(\mathrm{T} / \mathrm{Y})^{\mathrm{b}}\end{array}$ \\
\hline CA State & 245.49 & 4.729 & 36.42 & 0.388 & 1535.30 & 1949.26 & $0.25-0.47$ \\
SJV & 24.68 & 0.582 & 1.446 & 0.003 & 167.87 & 196.22 & $0.24-0.41$ \\
\hline
\end{tabular}

a. $\mathrm{T} / \mathrm{D}=$ Tons per day; $\mathrm{b} . \mathrm{T} / \mathrm{Y}=$ Tons per year. 
annual $\mathrm{CO}$ emissions from corn silage in this paper were much lower than the projected CO emissions from well-known categories in both the SJV and California in 2020, but comparable to the emissions in a sub-category of food and agricultural sources in the SJV (0.24- 0.41 tons per year from corn silage vs. 1.10 tons per year from food and agricultural sources). Because this paper is the first report of $\mathrm{CO}$ emissions from silage and has very likely underestimated the $\mathrm{CO}$ emissions due to limited observational data, it is necessary to improve the estimate of the $\mathrm{CO}$ emissions from silage and therefore improve the $\mathrm{CO}$ emission budget by conducting more research on silage emissions, including $\mathrm{CO}$ emissions from different kinds of silage crops, different methods of silage making, different silage aging times, and different management practices. Most importantly, research is needed on methodology to reduce $\mathrm{CO}$ emissions and provide safety guidance for farmers during silage making.

\section{Conclusions}

Elevated CO concentrations above ambient level were detected from two types of corn silages in two ensiling phases using three infrared spectrometers and three different sampling methods. An air sample collected in one Tedlar bag directly from the laboratory bucket silos during the early phase of ensiling was analyzed with a low-resolution FTIR spectrometer. Absorptions of CO were identified in the low-resolution FTIR spectrum at window $2025-2170 \mathrm{~cm}^{-1}$. CO concentration of $48.0 \mathrm{ppm}$ in the bucket silo was derived at this spectral window using a LINEFIT program. Air samples were collected with two Tedlar bags through a flux chamber at an Ag-Bag silage pile when it was opened several months after ensiling. These two air samples were analyzed using a high-resolution FTIR spectrometer. Absorptions of $\mathrm{CO}$ were identified at the high-resolution spectral window $2090-2210 \mathrm{~cm}^{-1}$ and CO concentrations of $6.83 \mathrm{ppm}$ were derived. The area emission rate of $\mathrm{CO}$ from the $\mathrm{Ag}$ - $\mathrm{Bag}$ silage pile was estimated at about $29.0 \mathrm{~mL} /\left(\right.$ hour $\cdot \mathrm{m}^{2}$ ) in volume or $33.7 \mathrm{mg} /\left(\right.$ hour $\cdot \mathrm{m}^{2}$ ) in mass. It may be an occupational safety concern if space containing silage, such as a silo, is not well vented because the $\mathrm{CO}$ concentration would continuously increase. Air samples collected through a flux chamber at Ag-Bag silage piles were also monitored in real-time by a high-resolution LGR analyzer and CO concentrations between 3 5 ppm were recorded (Figure 6). Despite the differences between offline FTIR analysis and real-time LGR measurements, both results confirmed that CO concentrations were elevated in the emissions of the Ag-Bag silage piles.

Because $\mathrm{N}_{2} \mathrm{O}$ emissions from laboratory bucket silo were observed in the initial phase of ensiling [13], several attempts were made to detect $\mathrm{N}_{2} \mathrm{O}$ in the Ag-Bag silage piles, including a traditional $\mathrm{N}_{2} \mathrm{O}$ gas analyzer based on broadband infrared absorptions, a high spectral resolution LGR $\mathrm{N}_{2} \mathrm{O} / \mathrm{CO}$ gas analyzer, and FTIR spectrometers. Air samples were collected with Tedlar bags from the Ag-Bag silage through a flux chamber and analyzed with a high-resolution FTIR spectrometer, but no $\mathrm{N}_{2} \mathrm{O}$ above the ambient level was observed. Surprisingly, noticeable $\mathrm{CO}$ absorptions were identified in the FTIR spectra of the air samples 
from the Ag-Bag silage. A high-resolution spectral window at $2090-2210 \mathrm{~cm}^{-1}$ suitable for $\mathrm{CO}$ retrieval was selected; see Figure 5, to derive the $\mathrm{CO}$ concentrations in the air samples from the Ag-Bag silage. Then, the low-resolution FTIR spectrum recorded earlier for bucket silo gas [13] was re-examined, and a lowresolution spectral window suitable for CO retrieval at $2025-2170 \mathrm{~cm}^{-1}$ was selected; see Figure 4, to derive the $\mathrm{CO}$ concentrations in the bucket silo gas. Reviewing the LGR data also revealed that $\mathrm{CO}$ concentrations were elevated in the emissions of Ag-Bag silage. This is how the high CO concentrations were discovered in air samples from both bucket silo and Ag-Bag silages. As mentioned earlier, $\mathrm{CO}$ measurements in the silage emissions came from two independent experiments and three spectrometers, provided more evidence supporting the observations of high $\mathrm{CO}$ concentrations in the silage emissions during different ensiling phases.

\section{Acknowledgements}

This work was partly supported by California Air Resources Board (CARB) under research contract \#11-325 and the Academic Federation Professional Development Award 2015-2016 by the University of California-Davis. YZ would like to thank the Karlsruhe Institute of Technology for hosting a 2-week visit.

\section{Conflicts of Interest}

The authors declare no conflicts of interest regarding the publication of this paper.

\section{References}

[1] OSHA (U.S. Department of Labor, Occupational Safety and Health Administration) (2012) OSHA Fact Sheet: Carbon Monoxide Poisoning. Occupational Safety and Health Administration, Washington DC. https://www.osha.gov/OshDoc/data_General_Facts/carbonmonoxide-factsheet.pdf

[2] Sillman, S. (1999) The Relation between Ozone, $\mathrm{NO}_{\mathrm{x}}$ and Hydrocarbons in Urban and Polluted Rural Environments. Atmospheric Environment, 33, 1821-1845. https://doi.org/10.1016/S1352-2310(98)00345-8

[3] Bufalini, J., Walker, T.A. and Bufalini, M.M. (1976) Ozone Formation Potential of Organic Compounds. Environmental Science \& Technology, 10, 908-912. https://doi.org/10.1021/es60120a016

[4] Finlayson-Pitts, B.J. and Pitts Jr., J.N. (1993) Atmospheric Chemistry of Tropospheric Ozone Formation: Scientific and Regulatory Implications. Air and Waste, 43, 1091-1100. https://doi.org/10.1080/1073161X.1993.10467187

[5] Robbins, R.C., Borg, K.M. and Robinson, E. (1968) Carbon Monoxide in the Atmosphere. Journal of the Air Pollution Control Association, 18, 106-110. https://doi.org/10.1080/00022470.1968.10469094

[6] Fazlzadeh, M., Rostami, R., Hazrat, S. and Rastgu, A. (2015) Concentrations of Carbon Monoxide in Indoor and Outdoor Air of Ghalyun Cafes. Atmospheric Pollution Research, 6, 550-555. https://doi.org/10.5094/APR.2015.061

[7] EPA (U.S. Environmental Protection Agency) (2021) Criteria Air Pollutants. https://www.epa.gov/criteria-air-pollutants 
[8] Lowry, T. and Schuman, L.M. (1956) "Silo-Filler's Disease"-A Syndrome Caused by Nitrogen Dioxide. Journal of the American Medical Association, 162, 153-160. https://doi.org/10.1001/jama.1956.02970200001001

[9] Wang, L.C. and Burries, R.H. (1960) Mass Spectrometric Study of Nitrogenous Gases Produced by Silage. Journal of Agricultural and Food Chemistry, 8, 239-242. https://doi.org/10.1021/jf60109a023

[10] Reid, W.S., Turnbull, J.E., Sabourin, H.M. and Ihnat, M. (1984) Silo Gas: Production and Detection. Canadian Agricultural Engineering, 25, 197-207.

[11] Hafner, S.D., Howard, C., Muck, R.E., Franco, R.B., Montes, F., Green, P.G., Mitloehner, F., Trabue, S.L. and Rotz, C.A. (2013) Emission of Volatile Organic Compounds from Silage: Compounds, Sources, and Implications. Atmospheric Environment, 77, 827-839. https://doi.org/10.1016/j.atmosenv.2013.04.076

[12] Hafner, S.D., Franco, R.B., Kung Jr., L., Rotz, C.A. and Mitloehner, F. (2014) Potassium Sorbate Reduces Production of Ethanol and 2 Esters in Corn Silage. J. Dairy Sci., 97, 7870-7878. https://doi.org/10.3168/jds.2014-8537

[13] Zhao, Y., Wexler, A.S., Hase, F., Pan, Y. and Mitloehner, F.M. (2016) Detecting Nitrous Oxide in Complex Mixtures Using FTIR Spectroscopy: Silage Gas. Journal of Environmental Protection, 7, 1719-1729. https://doi.org/10.4236/jep.2016.712139

[14] CDFA (California Department of Food and Agriculture) (2020) California Agricultural Statistics Review 2019-2020. California Department of Food and Agriculture, Sacramento. https://www.cdfa.ca.gov/Statistics/PDFs/2020_Ag_Stats_Review.pdf

[15] Shahbandeh, M. (2021) Number of Milk Cows in the United States from 1999 to 2020. US Department of Agriculture, Washington DC.

https://www.statista.com/statistics/194934/number-of-milk-cows-in-the-us-since-1 999/

[16] Shahbandeh, M. (2021) Production of Corn for Silage in the U.S. from 2000 to 2020. US Department of Agriculture, Washington DC.

https://www.statista.com/statistics/190886/production-of-corn-for-silage-in-the-ussince-2000/

[17] Shahbandeh, M. (2021) Top U States Based on Corn Production for Silage from 2014 to 2020. US Department of Agriculture, Washington DC. https://www.statista.com/statistics/191041/top-us-states-by-production-of-corn-for -silage/

[18] Malkina, I.L., Kumar, A., Green, P.G. and Mitloehner, F.M. (2011) Identification and Quantitation of Volatile Organic Compounds Emitted from Dairy Silages and Other Feedstuffs. Journal of Environmental Quality, 40, 28-36.

https://doi.org/10.2134/jeq2010.0302

[19] Li, M., Shan, G., Zhou, H., Buescher, W., Maack, C., Jungbluth, K.H., Lipski, A., Grantz, D.A., Fan, Y., Ma, D., Wang, Z., Cheng, Q. and Sun, Y. (2017) $\mathrm{CO}_{2}$ Production, Dissolution and Pressure Dynamics during Silage Production: Multi-Sensor-Based Insight into Parameter Interactions. Scientific Reports, 7, Article No. 14721. https://doi.org/10.1038/s41598-017-14187-1

[20] Zhao, Y., Strong, K., Kondo, Y., Koike, M., Matsumi, Y., Irie, H., Rinsland, C.P., Jones, N.B., Suzuki, K., Nakajima, H., Nakane, H. and Murata, I. (2002) Spectroscopic Measurements of Tropospheric CO, $\mathrm{C}_{2} \mathrm{H}_{6}, \mathrm{C}_{2} \mathrm{H}_{2}$, and $\mathrm{HCN}$ in Northern Japan. Journal of Geophysical Research: Atmospheres, 107, ACH 2-1-ACH 2-16. https://doi.org/10.1029/2001JD000748

[21] Wunch, D., Taylor, J.R., Fu, D., Bernath, P., Drummond, J.R., Midwinter, C., Strong, K. and Walker, K.A. (2007) Simultaneous Ground-Based Observations of 
$\mathrm{O}_{3}, \mathrm{HCl}, \mathrm{N}_{2} \mathrm{O}$, and $\mathrm{CH}_{4}$ over Toronto, Canada by Three Fourier Transform Spectrometers with Different Resolutions. Atmospheric Chemistry and Physics, 7, 1275-1292. https://doi.org/10.5194/acp-7-1275-2007

[22] Neal, W.M. and Becker, R.B. (1933) A Type of Laboratory Silo and Its Use with Crotalaria. Journal of Agricultural Research, 47, 617-625.

[23] Johnson, H.E., Merry, R.J., Davies, D.R., Kell, D.B., Theodorou, M.K. and Griffith, G.W. (2005) Vacuum Packing: A Model System for Laboratory-Scale Silage Fermentations. Journal of Applied Microbiology, 98, 106-113.

https://doi.org/10.1111/j.1365-2672.2004.02444.x

[24] Eklund, B. (1992) Practical Guidance for Flux Chamber Measurements of Fugitive Volatile Organic Emission Rates. Journal of the Air \& Waste Management Association, 42, 1583-1591. https://doi.org/10.1080/10473289.1992.10467102

[25] Parker, D., Ham, J., Woodbury, B., Cai, L., Spiehs, M., Rhoades, M., Trabue, S., Casey, K., Todd, R. and Cole, A. (2013) Standardization of Flux Chamber and Wind Tunnel Flux Measurements for Quantifying Volatile Organic Compound and Ammonia Emissions from Area Sources at Animal Feeding Operations. Atmospheric Environment, 66, 72-83. https://doi.org/10.1016/j.atmosenv.2012.03.068

[26] Hase, F., Blumenstock, T. and Paton-Walsh, C. (1999) Analysis of the Instrumental line Shape of High-Resolution Fourier Transform IR Spectrometers with Gas Cell Measurements and New Retrieval Software. Applied Optics, 38, 3417-3422. https://doi.org/10.1364/AO.38.003417

[27] Hase, F. (2012) Improved Instrumental Line Shape Monitoring for the GroundBased, High-Resolution FTIR Spectrometers of the Network for the Detection of Atmospheric Composition Change. Atmospheric Measurement Techniques, 5, 603-610. https://doi.org/10.5194/amt-5-603-2012

[28] Hase, F., Drouin, B.J., Roehl, C.M., Toon, G.C., Wennberg, P.O., Wunch, D., Blumenstock, T., Desmet, F., Feist, D.G., Heikkinen, P., De Mazière, M., Rettinger, M., Robinson, J., Schneider, M., Sherlock, V., Sussmann, R., Té, Y., Warneke, T. and Weinzierl, C. (2013) Calibration of Sealed HCl Cells Used for TCCON Instrumental Line Shape Monitoring. Atmospheric Measurement Techniques, 6, 3527-3537. https://doi.org/10.5194/amt-6-3527-2013

[29] Frey, M., Hase, F., Blumenstock, T., Groß, J., Kiel, M., Tsidu, G.M., Schäfer, K., Sha, M.K. and Orphal, J. (2015) Calibration and Instrumental Line Shape Characterization of a Set of Portable FTIR Spectrometers for Detecting Greenhouse Gas Emissions. Atmospheric Measurement Techniques, 8, 3047-3057.

https://doi.org/10.5194/amt-8-3047-2015

[30] USDA (United States Department of Agriculture) (2020) Milk Production. US Department of Agriculture, National Agricultural Statistics Service, Washington DC. https://www.nass.usda.gov/Publications/Todays_Reports/reports/mkpr0220.pdf

[31] USDA (United States Department of Agriculture) (2020) California Corn County Estimates. US Department of Agriculture, National Agricultural Statistics Service, Washington DC.

https://www.nass.usda.gov/Statistics_by_State/California/Publications/County_Esti mates/2020/202002CORNCNTY.pdf

[32] Amaral-Phillips, D.M. and McAllister, J. (2001) Planning the Yearly Forage and Commodity Needs for a Dairy Herd. University of Kentucky, Lexington. http://www2.ca.uky.edu/agcomm/pubs/asc/asc160/asc160.pdf

[33] USDA (United States Department of Agriculture) (2020) California Cattle County Estimates. US Department of Agriculture, National Agricultural Statistics Service, 
Washington DC.

https://www.nass.usda.gov/Statistics_by_State/California/Publications/County_Esti mates/2020/CATCNTYE_1920.pdf

[34] CARB (California Air Resources Board) (2018) CEPAM: 2016 SIP-Standard Emission Tool, Emission Projections by Summary Category Base Year: 2012.

https://www.arb.ca.gov/app/emsinv/fcemssumcat/fcemssumcat2016.php 